\title{
Malignant melanoma arising from a perianal fistula and harbouring a BRAF gene mutation: a case report
}

\author{
Conrado Martinez-Cadenas ${ }^{1 *}$, Nuria Bosch², Lucas Peñas², Esther Flores-Couce', Enrique Ochoa' ${ }^{1}$ Javier Munárriz ${ }^{3}$, \\ Juan P Aracil ${ }^{4}$, Marcos Tajahuerce ${ }^{5}$, Ramón Royo ${ }^{2}$, Rafael Lozoya ${ }^{6}$ and Enrique Boldó ${ }^{6}$
}

\begin{abstract}
Background: Melanoma of the anal region is a very uncommon disease, accounting for only $0.2-0.3 \%$ of all melanoma cases. Mutations of the BRAF gene are usually absent in melanomas occurring in this region as well as in other sun-protected regions. The development of a tumour in a longstanding perianal fistula is also extremely rare. More frequent is the case of a tumour presenting as a fistula, that is, the fistula being a consequence of the cancerous process, although we have found only two cases of fistula-generating melanomas reported in the literature.

Case Presentation: Here we report the case of a 38-year-old male who presented with a perianal fistula of four years of evolution. Histopathological examination of the fistulous tract confirmed the presence of malignant melanoma. Due to the small size and the central location of the melanoma inside the fistulous tract, we believe the melanoma reported here developed in the epithelium of the fistula once the latter was already formed. Resected sentinel lymph nodes were negative and the patient, after going through a wide local excision, remains disease-free nine years after diagnosis. DNA obtained from melanoma tissue was analysed by automated direct sequencing and the V600E (T1799A) mutation was detected in exon 15 of the BRAF gene.
\end{abstract}

Conclusion: Since fistulae experience persistent inflammation, the fact that this melanoma harbours a BRAF mutation strengthens the view that oxidative stress caused by inflammatory processes plays an important role in the genesis of BRAF gene mutations.

\section{Background}

Malignant melanomas of the anal region are a rare occurrence, accounting for only around $0.2-0.3 \%$ of all melanoma cases and $4 \%$ of anal cancers [1]. Diagnosis may be challenging, since perianal melanomas may be disguised as haemorrhoids [2] and more rarely as fissures [3] or perianal abscesses [4]. Prognosis is generally very poor [5], with five-year survival rates ranging between $6.7 \%$ and $16 \%[6,7]$.

The $B R A F$ gene encodes a serine/threonine kinase involved in the mitogen-activated protein kinase pathway (MAPK) [8]. Activating BRAF mutations are present in approximately $70 \%$ of cutaneous malignant

\footnotetext{
* Correspondence: martinezconrado@yahoo.es

'Molecular Biopathology Lab, Castellon Province Hospital, Ave. Doctor Clara 19, Castellon, 12002, Spain

Full list of author information is available at the end of the article
}

melanomas [9] and $82 \%$ of melanocytic naevi [10]. More than $90 \%$ of $B R A F$ mutations involve a single point mutation, T1799A, in codon 600 of exon 15, leading to a V600E amino acid substitution $[9,10]$. However, several studies have shown that BRAF mutations are very uncommon in melanomas arising in sun-protected areas [11-13]. These findings have suggested an association between the presence of $B R A F$ mutations in malignant melanomas and ultraviolet (UV) light exposure.

In this report we describe a case of malignant melanoma presenting in a perianal fistula. To the authors' knowledge, this clinical presentation has not been previously described in the scientific literature. To add to our knowledge of this rare entity, we have determined the mutational status of the BRAF gene in tumour tissue of the patient.

\section{() Biomed Central}




\section{Case presentation}

The patient was a 38-year-old male with a history of betathalassaemia minor with pseudopolycythemia and microcytosis. In May 2002 he underwent surgery for a perianal fistula of four years of evolution. Pathologic examination of the resected specimen revealed an abscessed fistulous tract with the presence of a small core of hyperpigmented and hyperplastic basal melanocytes arranged irregularly and forming a lentiginous pattern (Figure 1). A nest of epithelioid cells with atypical anaplastic nuclei, prominent nucleoli and abundant melanin was clearly discernible in the underlying dermis (Figure 1). Besides, features relatively specific for melanoma including absence of maturation and presence of mitoses in deep cells were also visible (Figure 1). Finally, other secondary characteristic also suggestive of melanoma was the abundant melanic pigment throughout the lesion, both in the depth of the lesion and in the upper portion of the epidermis, including the stratum corneum or horny layer of the epidermis.

In June 2002, once the diagnosis of melanoma in perianal fistula (Clark level III) had been confirmed by the pathologist, the patient went through a surgical extension of excision margins $(1 \mathrm{~cm})$ and a sentinel lymph node biopsy (one right and two left inguinal nodes). Both the extended margins and the sentinel lymph nodes produced negative results for tumour cells.

In order to discard the possibility of metastatic melanoma, the patient was also subjected to an abdominal ultrasound examination and a whole body CT scan, both without relevant findings. Serum levels of S-100 protein, a widely used melanoma marker, were also negative. The patient went through his latest follow-up in December 2010, and at the time of this report he remains free of disease.

\section{Methods}

\section{DNA extraction}

Five $\mu \mathrm{m}$ sections from tumour tissue were stained with a standard Haematoxylin-Eosin protocol. Histological slides were examined with a Leica DM2000 microscope and micrographs were taken using a Leica DMD108 microimaging device with integrated camera (Leica Microsystems, Wetzlar, Germany). Slides were then cleaned with $99 \%$ ethanol for 15 minutes and left to air-dry overnight. Melanoma tissue was then manually dissected from surrounding normal tissue with a sterile blade. DNA extraction from dissected melanoma tissue was performed using the ChargeSwitch gDNA Tissue Kit (Invitrogen, Carlsbad, USA) according to the manufacturer's instructions.

\section{Detection of the V600E mutation}

Melanoma DNA, a control sample (from peripheral blood of the same patient) and DNA extracted from melanoma
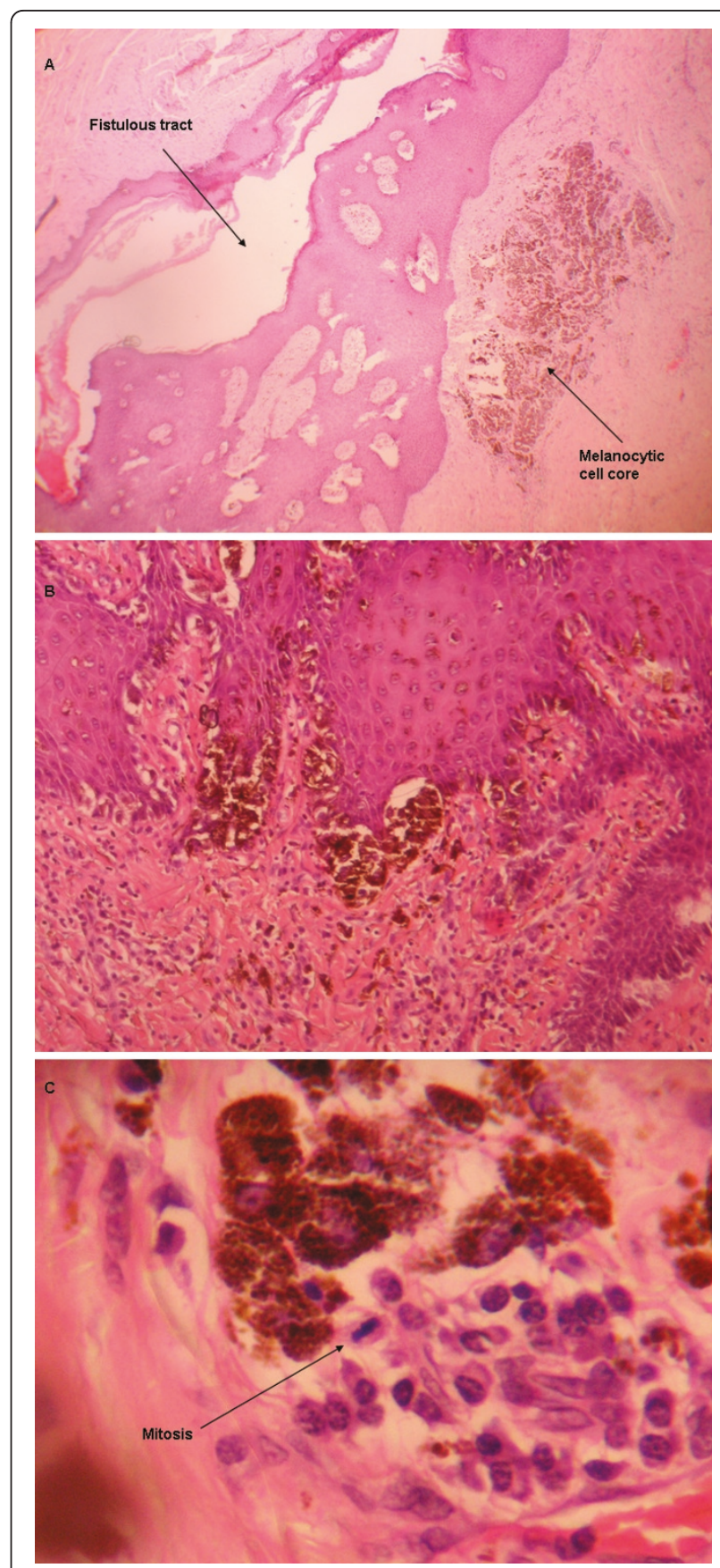

Figure 1 Photomicrographic images of the fistula melanoma. A) Fistulous tract course with nest of melanocytic cells (Haematoxylin-Eosin staining; magnification 4X). B) Closer view of the melanocytic cell core (H\&E; magnification 10X). C) Melanoma cancerous cells, including one undergoing mitosis (H\&E; magnification 40x).

cell line A375 were analysed for the V600E mutation at nucleotide 1799 of the $B R A F$ gene by direct automated DNA sequencing. PCR primer sequences used to amplify a 102-bp fragment containing nucleotide 1799 of exon 15 
were: 5'-GAAGACCTCACAGTAAAAATAGG TGA-3' (sense) and 5'-CCACAAAATGGATCCAGACA-3' (antisense). PCR reactions were carried out using about $100 \mathrm{ng}$ of melanoma DNA as template. Thermocycling conditions included a denaturation step at $95^{\circ} \mathrm{C}$ for 8 minutes, followed by 40 cycles of $95^{\circ} \mathrm{C}$ for 30 seconds, $56^{\circ} \mathrm{C}$ for 45 seconds and $72^{\circ} \mathrm{C}$ for 1 minute, plus a final extension cycle of $72^{\circ} \mathrm{C}$ for 10 minutes. Amplified products were purified using ExoSAP-IT (USB Corporation, Cleveland, USA) according to the manufacturer's instructions. Purified PCR products were then run on an ABI 3130 Genetic Analyzer (Applied Biosystems, Foster City, USA) and analysed using software supplied by the manufacturer.

All new sequence data contained in this study has been deposited in the GenBank sequence database [GenBank:HQ224878].

Appropriate ethical approval for this research was obtained from the Ethics and Clinical Research Committee (CEIC) of the Castellon Province Hospital. Written informed consent was obtained from the patient for the study and its reportings.

\section{Results}

High quality sequencing was obtained in both the $5^{\prime}$ and the 3' direction from the melanoma sample, the control DNA sample and melanoma cell line A375. The V600E mutation (T1799A) in exon 15 of the BRAF gene was present in the heterozygous state in the melanoma sample, but it was absent in non-tumour DNA obtained from peripheral blood of the same melanoma patient (Figure 2). As expected, the positive control sample, melanoma cell line A375, showed the V600E mutation in the homozygous state (Figure 2).

\section{Discussion}

The development of a tumour inside a longstanding fistula is an extremely infrequent event. More frequent is the case of a tumour presenting as a fistula, that is, the fistula being a consequence of the cancerous process. Occasionally, the inflammation and necrosis caused by the development and progression of a tumour stimulates the formation of a fistula. However, there are instances in which the fistula is not a secondary manifestation of the neoplasia, and its formation predates the development of the tumour. In these cases, the neoplastic transformation arises inside the longstanding fistula, probably due to the latter's chronic inflammatory nature [14]. We have found several cases in the literature in which a variety of different tumour types have developed inside a fistula once the latter was already formed, such as squamous cell carcinomas [15-17], basal cell carcinomas $[18,19]$ and mucinous adenocarcinomas [17,20-22].

As far as the authors are aware, the occurrence of a melanoma within a fistula has not been previously
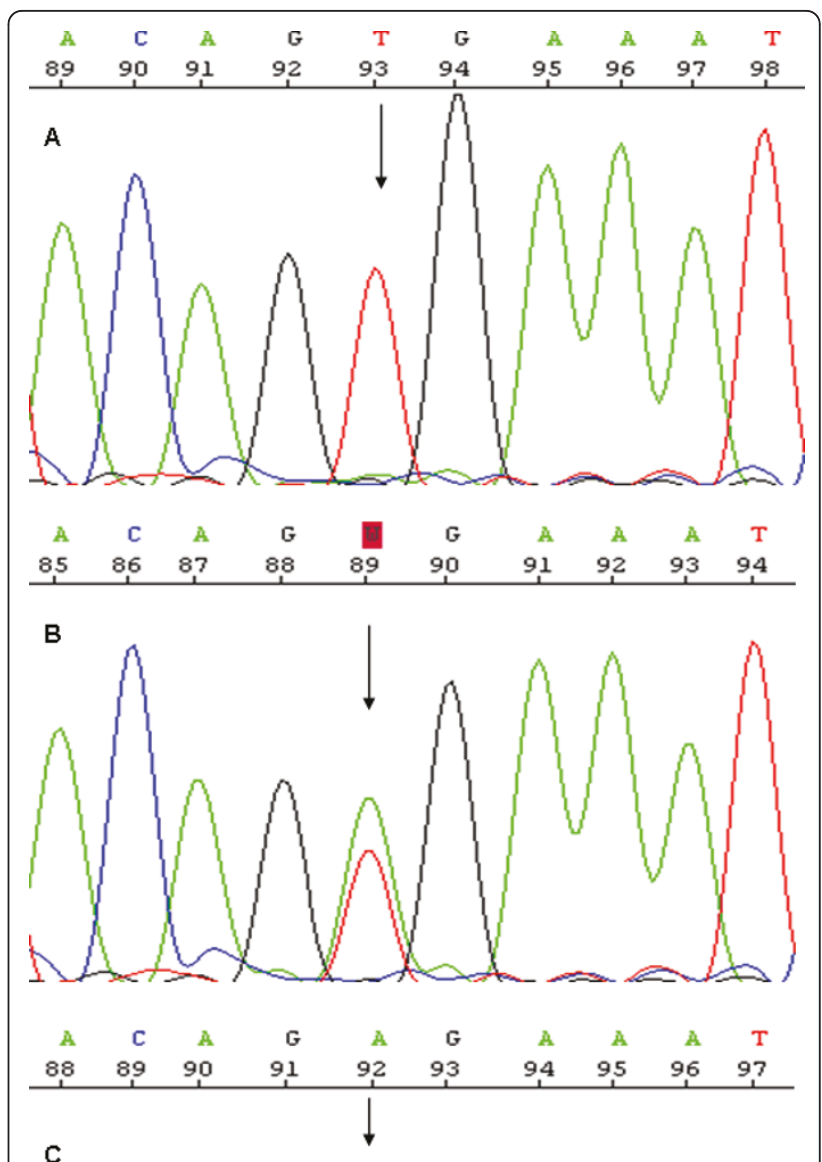

C

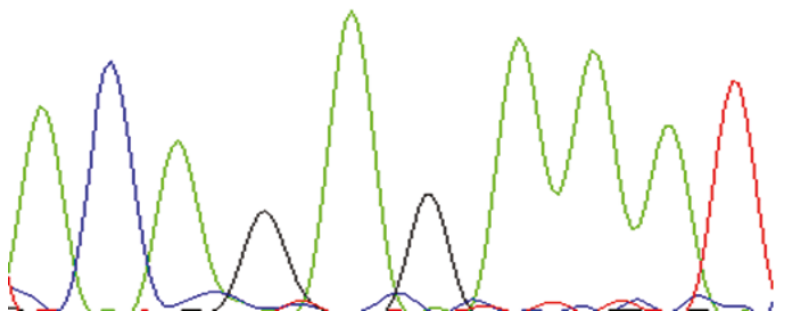

Figure 2 Sequence chromatograms of the negative control, the fistula melanoma and the positive control DNA samples. A) DNA from peripheral blood of the fistula melanoma patient with an arrow showing the wild-type genotype (the T allele in

homozygosis). B) DNA from the perianal fistula melanoma showing the T1799A mutation in heterozygosis (arrow). C) DNA from

melanoma cell line A375, with the mutation in the homozygous state.

described in the literature. We have found two published cases of melanomas presenting with fistulous formations, one concerning a biliary tract fistula [23] and another one presenting as a urethral fistula [24], in which the appearances of the fistulas were a consequence of the cancerous process.

In our patient, the fistula melanoma was quite small (Figure 1) and it was found by chance while the pathologist examined the stained histological sections of the 
fistula. The melanoma was located in the depth of the subcutaneous tissue, next to the fistulous tract, the interior of which was already epithelialised. It was surrounded by abundant inflammatory response and next to a lesion showing atypical lentiginous melanocytic hyperplasia (Figure 3). The presence of lentiginous hyperplasia suggested that the melanocytic lesion originated inside the fistulous tract and that we were indeed in front of a primary melanoma and not a metastasis (already ruled out by the whole body CT scan). On the other hand, the opening of the fistulous tract in the perianal skin epidermis did not contain signs of inflammation or malignant tissue (Figure 3), which ruled out the possibility of the fistula being a complication or a secondary manifestation of a cutaneous melanoma [14]. Therefore, we believe that the fistula predated the melanoma, not the other way around, and that it arose as a complication of the inflammatory lesion of the fistula.

Anal melanoma is an uncommon disease that affects patients of advanced age, usually appearing in the sixth or seventh decade of life $[25,26]$. However, Cagir and cols. found an increased incidence of anorectal melanomas in males aged 25 to 44 years living in the San Francisco area [27], and they proposed HIV infection as a risk factor for anorectal melanoma. But the HIV test in our patient (who was 38 years of age at diagnosis) was negative, and he had neither a previous history nor signs of other sexually-transmitted diseases.

The fact that this melanoma originated in a perianal location and inside a fistula also ruled out UV light exposure as a possible aetiological factor. Classic genetic mutations caused by UV exposure comprise $\mathrm{C}>\mathrm{T}$ and

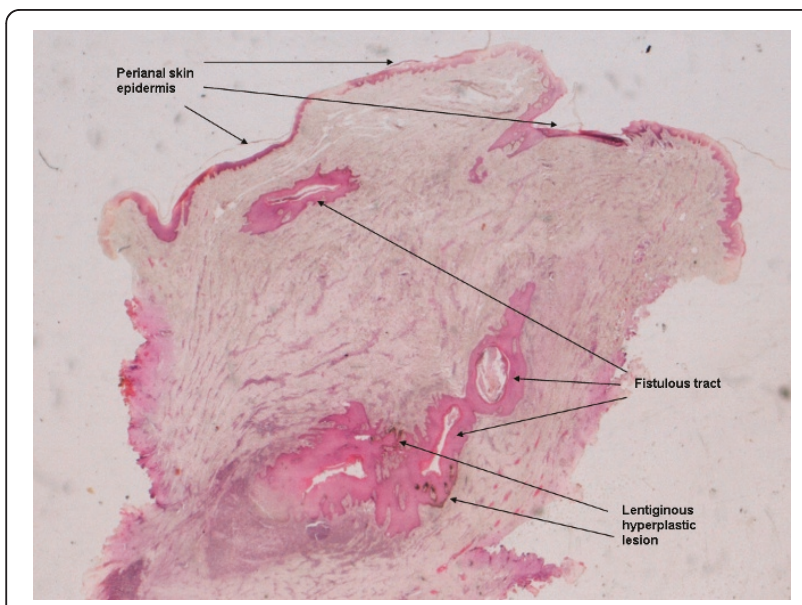

Figure 3 Photomicrographic image of a cross-section of the entire resected fistula piece. This picture of the entire resected piece (H\&E; magnification $2 \mathrm{X}$ ) shows the fistulous tract, the lentiginous melanocytic hyperplasia, and the perianal skin epidermis. Note that the lesion is located in the depth of fistula, not in the perianal epidermis.
$\mathrm{CC}>\mathrm{TT}$ transitions, although UV exposure generates oxygen-free radicals that also damage DNA and give rise to other types of base substitutions [28]. Even though $B R A F$ mutations occur more frequently in melanomas linked to sun exposure, the BRAF gene does not contain $\mathrm{C}>\mathrm{T}$ or $\mathrm{CC}>\mathrm{TT}$ transitions typical of UVinduced damage. The commonest $B R A F$ mutation by far is T1799A (V600E), a T $>\mathrm{A}$ transversion present in more than $90 \%$ of all $B R A F$-mutated melanomas and naevi.

Due to the detection of the V600E BRAF mutation in this fistula melanoma, it was decided not to look for alterations in genes such as CCND1 or KIT, more frequently mutated in acral and mucosal melanomas [29], since concomitant mutations in $B R A F$ and in genes such as KIT or CCND1 are extremely rare [29]. Regarding this, it has to be understood that, although this melanoma arose in the perianal region, it was not a case of mucosal melanoma, since it did not originate in the anal mucous membrane of the patient.

BRAF mutations, including T1799A, have occasionally been found in anal mucosal melanomas [30] and in other tumours not associated with UV exposure [9], such as thyroid cancer [31,32], colorectal cancer [33-35], pancreatic cancer $[36,37]$ or ovarian cancer $[38,39]$. The development of all these tumour types may, in turn, be related to inflammatory processes [12], in the same way as cutaneous melanoma is associated with inflammation of the skin caused by UV exposure [40]. Accordingly, oxidative stress caused by inflammation may be in part responsible for mutations in the BRAF gene [12]. Since fistulae are environments that experience permanent inflammatory processes, the fact that the fistula melanoma reported here is carrying the $T 1799 \mathrm{~A}$ transversion supports the hypothesis that oxidative damage caused by free radicals plays a role in the genesis of $B R A F$ mutations.

Obviously, we are not presuming that all inflammation must cause BRAF mutations, but that persistent or chronic inflammatory processes in the absence of UV exposure (such as thyroiditis in thyroid cancer [31], chronic pancreatitis in pancreatic cancer [37], chronic bowel inflammation in colon cancer [41] and, in our case, a longstanding fistula in a melanoma), can probably make the $B R A F$ gene more susceptible to genetic mutations via an as yet unidentified oxidative stress lesion.

As to the management of the perianal fistula melanoma, this case illustrates the benefits provided by the use of sentinel lymph node biopsy. Similarly to anorectal melanoma cases [42], the sentinel lymph nodes were located in the groin, not in the presacral region. As mentioned above, all three nodes dissected were free of tumour cells. After ruling out abdominoperineal resection [43], wide local excision (WLE) appears to obtain 
general good results when used as the initial treatment of choice in melanomas of the anal region $[5,26]$. Our case can only corroborate this, since nine years after WLE our patient remains healthy and without signs of relapse.

\section{Conclusions}

The fact that the melanoma described in this report arose inside a fistula may set it apart from other anal and perianal melanomas, as well as from mucosal melanomas in general. In our opinion, and due to the symptoms occasioned by the presence of the fistula, this melanoma was caught at a very early stage compared to other anorectal or perianal melanomas. The presence of a BRAF mutation, usually absent in other anal melanomas, also suggests different aetiological factors contributing to the development of this particular melanoma, with inflammatory processes and oxidative stress damage being possibly among them.

\section{Acknowledgements and Funding}

We gratefully acknowledge Dr. Jose Carlos Garcia-Borron and Dr. Maria Carmen Turpin from the Department of Biochemistry and Molecular Biology, University of Murcia, Spain, for kindly providing us with the A375 melanoma cell line.

This work was supported by a grant from the Fundacion de la CV Hospital Provincial de Castellon to C.M-C. The authors declare that the funding body, the Fundacion de la CV Hospital Provincial de Castellon, had no role whatsoever in the design, data collection, data analyses, interpretation of results, and/or manuscript writing or publication of this study.

\section{Author details}

${ }^{1}$ Molecular Biopathology Lab, Castellon Province Hospital, Ave. Doctor Clara 19, Castellon, 12002, Spain. ²Pathology Service, Castellon Province Hospital, Ave. Doctor Clara 19, Castellon, 12002, Spain. ${ }^{3}$ Oncology Service, Castellon Province Hospital, Ave. Doctor Clara 19, Castellon, 12002, Spain. ${ }^{4}$ Plastic Surgery Service, Castellon Province Hospital, Ave. Doctor Clara 19, Castellon, 12002, Spain. ${ }^{5}$ Nuclear Medicine Service, Castellon Province Hospital, Ave. Doctor Clara 19, Castellon, 12002, Spain. 'Surgical Oncology Unit, Castellon Province Hospital, Ave. Doctor Clara 19, Castellon, 12002, Spain.

\section{Authors' contributions}

CM-C participated in the study design, performed the molecular genetic studies and sequence analysis, and drafted the manuscript. NB and LP performed the histopathological staining, took all photomicrographic images and participated in the draft of the manuscript. EF-C participated in the molecular genetic studies. EO participated in the study design and in manuscript critical revision. JM, JPA and MT participated in the study design and coordination, in the acquisition of clinical data and in manuscript revision. RR participated in the histopathological staining and in the study design. RL participated in the study design and coordination, as well as in manuscript revision. EB conceived the study, participated in its design and coordination and helped to draft the manuscript. All authors read and approved the final manuscript.

\section{Competing interests}

The authors declare that they have no competing interests.

Received: 28 December 2010 Accepted: 9 August 2011 Published: 9 August 2011

\section{References}

1. Weinstock MA: Epidemiology and prognosis of anorectal melanoma. Gastroenterology 1993, 104:174-8.
2. Fripp VT, Esquivel J, Cerruto CA: Perianal melanoma disguised as hemorrhoids: case report and discussion. J Natl Med Assoc 2005, 97:726-31.

3. Debets JM, Lijnen RL, Willig AP: [Diagnostic image (84). A woman with persisting perianal fissures]. Ned Tijdschr Geneeskd 2002, 146:718.

4. Yadoo S, Kessler E: Malignant melanoma presenting as peri-anal abscess. Am J Proctol 1971, 22:108-10.

5. Thibault C, Sagar P, Nivatvongs S, Ilstrup DM, Wolff BG: Anorectal melanoma - an incurable disease? Dis Colon Rectum 1997, 40:661-8.

6. Cooper PH, Mills SE, Allen MS Jr: Malignant melanoma of the anus: report of 12 patients and analysis of 255 additional cases. Dis Colon Rectum 1982, 25:693-703.

7. Brady MS, Kavolius JP, Quan SH: Anorectal melanoma. A 64-year experience at Memorial Sloan-Kettering Cancer Center. Dis Colon Rectum 1995, 38:146-51.

8. Peyssonnaux C, Eychène A: The Raf/MEK/ERK pathway: new concepts of activation. Biol Cell 2001, 93:53-62.

9. Davies H, Bignell GR, Cox C, Stephens P, Edkins S, Clegg S, Teague J, Woffendin H, Garnett MJ, Bottomley W, Davis N, Dicks E, Ewing R, Floyd Y, Gray K, Hall S, Hawes R, Hughes J, Kosmidou V, Menzies A, Mould C, Parker A, Stevens C, Watt S, Hooper S, Wilson R, Jayatilake H, Gusterson BA, Cooper C, Shipley J, et al: Mutations of the BRAF gene in human cancer. Nature 2002, 417:949-54.

10. Pollock PM, Harper UL, Hansen KS, Yudt LM, Stark M, Robbins CM, Moses TY, Hostetter G, Wagner U, Kakareka J, Salem G, Pohida T, Heenan P, Duray P, Kallioniemi O, Hayward NK, Trent JM, Meltzer PS: High frequency of BRAF mutations in nevi. Nat Genet 2003, 33:19-20.

11. Cohen Y, Rosenbaum E, Begum S, Goldenberg D, Esche C, Lavie O, Sidransky D, Westra WH: Exon 15 BRAF mutations are uncommon in melanomas arising in non sun-exposed sites. Clin Cancer Res 2004, 10:3444-7.

12. Edwards RH, Ward MR, Wu H, Medina CA, Brose MS, Volpe P, Nussen-Lee S, Haupt HM, Martin AM, Herlyn M, Lessin SR, Weber BL: Absence of BRAF mutations in UV-protected mucosal melanomas. J Med Genet 2004, 41:270-2.

13. Wong CW, Fan YS, Chan TL, Chan AS, Ho LC, Ma TK, Yuen ST, Leung SY: BRAF and NRAS mutations are uncommon in melanomas arising in diverse internal organs. J Clin Pathol 2005, 58:640-4

14. Welch GH, Finlay IG: Neoplastic transformation in longstanding fistula-inano. Postgrad Med J 1987, 63:503-4.

15. Abboud B, Ingea H, Tayar C, Abadjian G: [Epidermoid carcinoma developing in a chronic anal fistula]. Presse Med 2000, 29:786-7.

16. Seya T, Tanaka N, Shinji S, Yokoi K, Oguro T, Oaki Y, Ishiwata T, Naito Z, Tajiri T: Squamous cell carcinoma arising from recurrent anal fistula. $J$ Nippon Med Sch 2007, 74:319-24.

17. Thomas M, Bienkowski R, Vandermeer TJ, Trostle D, Cagir B: Malignant transformation in perianal fistulas of Crohn's disease: a systematic review of literature. J Gastrointest Surg 2010, 14:66-73.

18. Mees K, Löhrs U: [Basal cell carcinoma developing in a preauricular fistula (author's transl)]. Laryngol Rhinol Otol (Stuttg) 1978, 57:359-62.

19. Kulaylat MN, Doerr RJ, Karamanoukian H, Barrios G: Basal cell carcinoma arising in a fistula-in-ano. Am Surg 1996, 62:1000-2.

20. Erhan Y, Sakarya A, Aydede H, Demir A, Seyhan A, Atici E: A case of large mucinous adenocarcinoma arising in a long-standing fistula-in-ano. Dig Surg 2003, 20:69-71.

21. Venclauskas L, Saladzinskas Z, Tamelis A, Pranys D, Pavalkis D: Mucinous adenocarcinoma arising in an anorectal fistula. Medicina (Kaunas) 2009, 45:286-90.

22. lesalnieks I, Gaertner WB, Gla $\beta$ H, Strauch U, Hipp M, Agha A, Schlitt HJ: Fistula-associated anal adenocarcinoma in Crohn's disease. Inflamm Bowel Dis 2010, 16:1643-1648.

23. Larmi TK: Malignant melanoma of the gallbladder. Report of a case resulting in an external biliary fistula. Acta Chir Scand 1960, 119:502-5.

24. Morita T, Suzuki H, Goto K, Hirota N, Tokue A: Primary malignant melanoma of male urethra with fistula formation. Urol Int 1991, 46:114-5.

25. Droesch JT, Flum DR, Mann GN: Wide local excision or abdominoperineal resection as the initial treatment for anorectal melanoma? Am J Surg 2005, 189:446-9.

26. Homsi J, Garrett C: Melanoma of the anal canal: a case series. Dis Colon Rectum 2007, 50:1004-10. 
27. Cagir B, Whiteford MH, Topham A, Rakinic J, Fry RD: Changing epidemiology of anorectal melanoma. Dis Colon Rectum 1999, 42:1203-8.

28. Jhappan C, Noonan FP, Merlino G: Ultraviolet radiation and cutaneous malignant melanoma. Oncogene 2003, 22:3099-112.

29. Curtin JA, Busam K, Pinkel D, Bastian BC: Somatic activation of KIT in distinct subtypes of melanoma. J Clin Oncol 2006, 24:4340-6.

30. Helmke BM, Mollenhauer J, Herold-Mende C, Benner A, Thome M, Gassler N, Wahl W, Lyer S, Poustka A, Otto HF, Deichmann M: BRAF mutations distinguish anorectal from cutaneous melanoma at the molecular level. Gastroenterology 2004, 127:1815-20.

31. Kimura ET, Nikiforova MN, Zhu Z, Knauf JA, Nikiforov YE, Fagin JA: High prevalence of BRAF mutations in thyroid cancer: genetic evidence for constitutive activation of the RET/PTC-RAS-BRAF signaling pathway in papillary thyroid carcinoma. Cancer Res 2003, 63:1454-7.

32. Xing M: BRAF mutation in papillary thyroid cancer: pathogenic role, molecular bases, and clinical implications. Endocr Rev 2007, 28:742-62

33. Li WQ, Kawakami K, Ruszkiewicz A, Bennett G, Moore J, lacopetta B: BRAF mutations are associated with distinctive clinical, pathological and molecular features of colorectal cancer independently of microsatellite instability status. Mol Cancer 2006, 5:2.

34. Jass JR: Classification of colorectal cancer based on correlation of clinical, morphological and molecular features. Histopathology 2007, 50:113-30.

35. Nagasaka T, Koi M, Kloor M, Gebert J, Vilkin A, Nishida N, Shin SK, Sasamoto H, Tanaka N, Matsubara N, Boland CR, Goel A: Mutations in both KRAS and BRAF may contribute to the methylator phenotype in colon cancer. Gastroenterology 2008, 134:1950-60.

36. Calhoun ES, Jones JB, Ashfag R, Adsay V, Baker SJ, Valentine V, Hempen PM, Hilgers W, Yeo CJ, Hruban RH, Kern SE: BRAF and FBXW7 (CDC4, FBW7, AGO, SEL10) mutations in distinct subsets of pancreatic cancer: potential therapeutic targets. Am J Pathol 2003, 163:1255-60.

37. Schönleben F, Qiu W, Bruckman KC, Ciau NT, Li X, Lauerman MH, Frucht $H$, Chabot JA, Allendorf JD, Remotti HE, Su GH: BRAF and KRAS gene mutations in intraductal papillary mucinous neoplasm/carcinoma (IPMN/ IPMC) of the pancreas. Cancer Lett 2007, 249:242-8.

38. Singer G, Oldt R, Cohen Y, Wang BG, Sidransky D, Kurman RJ, Shih leM: Mutations in BRAF and KRAS characterize the development of low-grade ovarian serous carcinoma. J Natl Cancer Inst 2003, 95:484-6.

39. Mayr D, Hirschmann A, Löhrs U, Diebold J: KRAS and BRAF mutations in ovarian tumours: a comprehensive study of invasive carcinomas, borderline tumours and extraovarian implants. Gynecol Oncol 2006, 103:883-7.

40. Rees JL: The genetics of sun sensitivity in humans. Am J Hum Genet 2004, 75:739-51

41. Aust DE, Haase M, Dobryden L, Markwarth A, Löhrs U, Wittekind C, Baretton GB, Tannapfel A: Mutations of the BRAF gene in ulcerative colitis-related colorectal carcinoma. Int J Cancer 2005, 115:673-7.

42. Olsha O, Mintz A, Gimon Z, Gold Deutch R, Rabin I, Halevy A, Reissman P: Anal melanoma in the era of sentinel lymph node mapping: a diagnostic and therapeutic challenge. Tech Coloproctol 2005, 9:60-2.

43. Yap LB, Neary P: A comparison of wide local excision with abdominoperineal resection in anorectal melanoma. Melanoma Res 2004, 14:147-50

Pre-publication history

The pre-publication history for this paper can be accessed here: http://www.biomedcentral.com/1471-2407/11/343/prepub

doi:10.1186/1471-2407-11-343

Cite this article as: Martinez-Cadenas et al:: Malignant melanoma arising from a perianal fistula and harbouring a BRAF gene mutation: a case report. BMC Cancer 2011 11:343.

\section{Submit your next manuscript to BioMed Central and take full advantage of:}

- Convenient online submission

- Thorough peer review

- No space constraints or color figure charges

- Immediate publication on acceptance

- Inclusion in PubMed, CAS, Scopus and Google Scholar

- Research which is freely available for redistribution

Submit your manuscript at www.biomedcentral.com/submit
C Biomed Central 